\title{
BRITISH PARTY SYSTEM CHANGE. THE IMPACT OF CHANGING VOTERS, DEVOLUTION AND CABINET COALITION ON THE TWO-PARTY SYSTEM
}

\begin{abstract}
The article describes the analysis of the modern British party system in the age of changes and transformations. In particular, it analyzes the changes in the electorate as well as the legal-institutional conditions which, in consequence, led to a shift in the balance of power between the political parties on the parliamentary level that occurred after the 2010 general election. Forming a coalition in the Parliament and the Cabinet marked the beginning of an ideologically and politically difficult rule of two parties which both politicians and voters alike had to learn. I argue that the above circumstances led to a certain "crisis" not only in the way administration is handled but also in the society's political participation. Simultaneously, it relates to what I view as a change in the British party system. The present article largely focuses on the transformations within the British party system that occurred in the early $21^{\text {st }}$ century, on the genesis of the processes which affects the transformations in the above system, as well as on the causes and effects of these phenomena.
\end{abstract}

\section{Key words}

British party system, coalition government, devolution, general elections, political participation

* Izabela Kapsa, Political Science Institute, Kazimierz Wielki University in Bydgoszcz, Poland, izabela.kapsa@ukw.edu.pl. 